\title{
Legal Protection of Traditional Cultural Expression as a Copyright in Indonesia
}

\author{
Nenny Dwi Ariani \\ Law Department \\ Lampung University \\ Lampung, Indonesia \\ nennydwiariani@gmail.com
}

\author{
Rohaini \\ Law Department \\ Lampung University \\ Lampung, Indonesia \\ rohaini.arifien81@gmail.com
}

\author{
Sunaryo \\ Law Department \\ Lampung University \\ Lampung, Indonesia \\ sunaryo.fhunila@gmail.com
}

\begin{abstract}
Indonesia that has a huge of natural resources and human resources with all its creativity has created various kinds of intellectual creation in the field of arts, literature, and knowledge. That creations of the ancestral can be called by Traditional Cultural Expressions that must be protected by the law. It is not only because it has sacred values that still exist in the custom society in Indonesia, but also has a high rate of economic values. Traditional Cultural Expressions as copyrights need to get the protection of the law to avoid confession by another country, for example, Pendet Dance, Wayang, and Reog Ponorogo that claimed as traditional property of Malaysia. The form of law protection of Traditional Cultural Expressions as copyrights has already grown. In the Law No.19 of 2002 on Copyrights, Traditional Cultural Expressions have only meaning as folklore. And then, throughout Law No.28 of 2014 on Copyrights, Traditional Cultural Expressions has a wide meaning. It means one or combination expression form of verbal textual, music, dance, theater, fine arts, and custom ceremony.
\end{abstract}

Keywords-Legal Protection, Traditional Cultural Expression, Copyrights

\section{INTRODUCTION}

Indonesia has a wealth of natural resources and also has a wealth of human resources that have created intellectual property. The diversity that exists in Indonesia has given rise to various kinds of intellectual creations within the scope of art, literature, and science. In this regard, according to Koentjaraningrat, there are approximately 900 ethnic groups in Indonesia. From this diversity, various forms of products based on the culture of each ethnic group have been developed [1]

The work of the ancestors of the Indonesian Nation is an Expression of Traditional Culture (EBT) that must be protected by law. This is because these intellectual works not only reflect the cultural diversity of the country but also have great economic value, including the sacred values that continue to be recognized by Native Indonesians. Efforts to correct the law are immediately made by the Indonesian government so that the activities of the national cultural heritage are not recognized by the state or other parties, especially in the case of claims to traditional knowledge and expression, as the Indonesian people have experienced. Must be done. Traditional Indonesian culture of Malaysia. The mysterious Malaysian Discovery Channel ad identifies the dance of the Pendet, Wayang, and Reog Ponorogo as a traditional Malaysian property. They are all traditional Indonesian cultural expressions.

The issue of the importance of legal protection for $\mathrm{PT}$ and EBT in Indonesia has begun to become a concern in the last few years when the issue of allegations of claims for the Reog Ponorogo and Pendet dances by Malaysia was widely publicized in the mass media. However, this issue has been a subject of debate at the international level since 2001, when the first session of the Intergovernmental Committee on Intellectual Property and Genetic Resources, Traditional Knowledge and Folklore (IGC GRTKF) was held at the WIPO headquarters in Geneva, Switzerland. The substance of PT and EBT has been the subject of debate since 1967 when the Bern Convention for the Protection of Literary and Artistic Works added Article 15.4, which states that works that have not been published and whose authors are not known, can be protected as Copyrights. if it is suspected that the creator is a citizen of a party to the convention. In addition, states parties to this convention are required to appoint competent authorities to provide protection [2].

One example of the manifestation of the creative thoughts and ideas of the ancestors of the Indonesian nation as outlined in the form of works of art as expressions of traditional culture that need to be protected immediately is Tapis and Siger Lampung which is traditional crafts because of the equipment used in making the basic cloth and various motifs the decorations reflect sacred values and are made by craftsmen with certain skills [3]. 
The problem that will be discussed in this research is how is the legal protection of EBT as copyright in Indonesia?.

This study uses a normative legal approach, including a legal approach, a case study approach, a historical approach, a conceptual approach, and a comparative approach. A normative legal approach is pursued through the study of legal grounds, norms of legal regulation, legal opinions (doctrinals), and legal and non-legal literature, in the form of opinions and perspectives from relevant sources. Supported by an empirical approach. In the main problem of this study.

\section{DISCUSSION}

With the advancement of science and technology and the growing awareness of the international community about the existence of the traditional intellectual property, a new field, namely new intellectual property rights, has emerged in addition to the previously known intellectual property (IP). To do this, this includes the protection of genetic resources, traditional knowledge, traditional cultural expressions, or folklore. Negotiations in this new area have often been conducted by the World Intellectual Property Organization (WIPO) since 2000. Later, WIPO formed an intergovernmental committee on intellectual property and genetic resources, traditional knowledge, and traditional cultural expression/folklore. WIPO equates the concept of traditional cultural expression (EBT) with folklore, but the folklore is part of EBT, or oral tradition [4]. EBT, on the other hand, is an element of traditional heritage as a national culture, a common resource that is continuously developed, maintained, or maintained by a particular traditional community or society, or a particular traditional social organization. It is an incorporated artistic creation [5].

Folklore is all forms of human creativity that grow and develop and are communally owned by a group of indigenous peoples or a particular community. In this regard, Agus Sardjono provides additional definitions related to folklore which also includes visible expressions, such as art products, especially drawings, designs, paintings (including body paintings), as well as various handicrafts, musical instruments, and various forms. architectural. For an expression to qualify as folklore, it must indicate the existence of individual or collective intellectual activity, which is a feature of the identity and heritage of a community and has been preserved, used, or developed by that community, or by individuals who have rights or responsibilities. to do so following the laws and customary or customary practices in the community [6].

The previous definition of folklore is in Section 19 of the 2001 Doha Declaration. This broadened the scope of the discussion to include traditional knowledge and cultural expression. The statement stated that the TRIPS Council should also take into account the relationship between TRIPS and the Convention on
Biological Diversity, as well as the protection of traditional knowledge and folklore [7].

Indonesia is a country rich in traditional knowledge and traditional cultural expressions. This great potential is a form of traditional knowledge and cultural expressions that still have to be protected by the state (in this case the government). Until now, the government's attention to traditional knowledge and cultural expressions is still limited to the recording process, although efforts to preserve them are still ongoing. Whereas in the current era of free trade it is necessary to protect the potential that comes from traditional knowledge. These potentials must be administered to make clear ownership of traditional knowledge by each country [7].

As regulated in Article 10 of Law Number 19 of 2002 on Copyright, the state holds Copyrights for works of prehistoric heritage, history, and other national cultural objects in the form of folklore and folk cultural products that become common property, such as stories, saga, fairy tales, legends, chronicles, songs, crafts, choreography, dances, calligraphy and other works of art. In this rule, it is not clear about the subject of the copyright holder. The authority, procedure, and substance that regulates this right holder have not been explicitly regulated. Article 10 paragraph (3) of this law stipulates that the mechanism for the permission to publish or reproduce the work is left to the relevant agency in the matter. Further regulation regarding this matter is regulated in government regulation as a derivative of this law, but until it is replaced with a new law the regulation has not yet been issued.

Based on the explanation in Article 10, Paragraph 3 of the Copyright Act, the government states that it can prevent monopoly, commercialization, destructive acts, and commercial use to protect the private traditions and cultural properties of others. increase. Permission of the Republic of Indonesia as a copyright holder. The purpose of this provision is to avoid acts by foreign parties that may impair cultural value.

The concept of traditional knowledge and the form of traditional cultural expression are so closely related to the region as the owner of traditional knowledge that both the state government and the district/city have important missions and functions in its protection. I'm waiting. Government administration in the concept of local autonomy emphasizes the missions and functions of governments that are divided among the central government, state governments, and local / city administrations

Protection of expression of folklore as specified in Article 10 paragraph (1) of Law No 19 of 2002 on Copyright that copyrights on pre-historic, historical, and other national cultural objects are held and controlled by the state. In particular, the regulation of expression of folklore is regulated in Article 10 
paragraph (2) and paragraph (3), which is determined as follows:

Paragraph (2) The state holds the copyright on folklore and folk cultural products that are common property, such as stories, saga, fairy tales, legends, chronicles, songs, handicrafts, choreography, dances, calligraphy, and other works of art;

Paragraph (3) To publish or reproduce the work referred to in paragraph (2), a person who is not an Indonesian citizen must first obtain permission from the relevant agency in that matter.

The provisions of Article 10 of Law no. 19 of 2002 is a form of acknowledgment that past creations which are relics of the ancestors, along with other creations without the name of the creator (no name) which subsequently became the categorization of the public domain, because the protection period for the work has been ended. Folklore is intended as a collection of traditional creations created by groups or individuals of society, as explained in the explanation of Law No. 19 of 2002, folklore, folk poetry, folk songs. , Traditional musical instruments, folk dances, traditional games, paintings, paintings, sculptures, sculptures, mosaics, jewelry, handicrafts, clothing, musical instruments, generations including works of art such as traditional weaving [8].

A more comprehensive understanding of folklore, along with the special characteristics inherent in it, namely [9]:

- Taught and implemented from generation to generation;

- The knowledge that includes knowledge about the environment and its relationship with everything;

- It is holistic, so it cannot be separated from the community that built it;

- It is a way of life, which is used jointly by the community, and therefore there are community values.

Finally, at the end of 2014, the copyright law enacted in Indonesia gave enough hope for the protection of traditional cultural expressions. Law Number 19 of 2002 was replaced with Law Number 28 of 2014 on Copyright. This is stated in Article 38 of Law No. 28 of 2014 on Copyright (UUHC) as follows:

- Copyrights for traditional cultural expressions are held by the state;

- The state is obliged to create, maintain and maintain an inventory of traditional forms of cultural expression following paragraph (1);

- When using traditional cultural expressions within the meaning of paragraph (1), it is necessary to take into account the values of living in society;

- Further provisions regarding state copyright in traditional cultural forms according to paragraph (1) are regulated by state ordinances.

Elucidation of Article 38 paragraph (1) that what is meant by traditional cultural expressions includes one or a combination of the following forms of expression:

- Oral and written text in the form of prose or poetry about the content of various topics and messages. This can be in the form of a literary work or a useful narrative;

- music, including vocal, instrumental, or a combination thereof;

- movement, including dance;

- theater, including puppet shows and folk plays;

- Art in both 2D and 3D forms made of various materials such as leather, wood, bamboo, metal, stone, ceramics, paper, textiles, or combinations thereof; and

- traditional ceremonies.

Based on the definition of Traditional Cultural Expression above, it gives an implicit understanding that folklore is part of Traditional Cultural Expression. Meanwhile, regarding the time limit for copyright on EBT which is held by the state according to the provisions of Article 60 paragraph (1) UUHC, which is valid indefinitely.

\section{CONCLUSION}

The works of the ancestors of the Indonesian people, including in the fields of art, literature, and traditional ceremonies, are Traditional Cultural Expressions as part of copyright that must be protected. Legal protection of Traditional Cultural Expressions as copyright has developed, which was originally only interpreted as folklore, namely oral traditions based on Law Number 19 of 2002 which was considered not sufficient to protect, so that in the end through Law Number 28 of 2014, Traditional Cultural Expression was interpreted to include one or more of the following: a combination of forms of textual verbal expression, music, motion, theatre, fine arts, and traditional ceremonies.

\section{REFERENCES}

[1] Ariani, Nenny Dwi, Upaya Pemerintah Daerah Dalam Melindungi Kain Tapis dan Siger Lampung Sebagai Ekspresi Budaya Tradisional, Tesis Program Magister Ilmu Hukum Universitas Diponegoro, Semarang, 2015.

[2] Damian, Eddy. Glosarium Hak Cipta dan Hak Terkait, Alumni, Bandung, 2012.

[3] Danandjaya, James. Folklor Indonesia: Ilmu Gosip, Dongeng, dan Lain-lain, Grafiti, Jakarta, 2002. 
[4] Margono, Suyud. Hukum Hak Cipta Indonesia: Teori dan Analisis Harmonisasi Ketentuan World Trade Organization (WTO)-TRIPs Agreement, Ghalia Indonesia, Bogor, 2010.

[5] Sardjono, Agus. Hak Kekayaan Intelektual dan Pengetahuan Tradisional, Alumni, Bandung, 2010.

[6] Sudarmanto, Produk Kategori Indikasi Gopgrafis Potensi Kekayaan Intelektual Masyarakat Indonesia, Lembaga Pengkajian Hukum Internasional Fakultas Hukum Universitas Indonesia, Depok, 2005.

[7] Fathoni, Kebijakan Perlindungan Pengetahuan Tradisional dan Ekspresi Budaya di Indonesia: Studi Peran Pemerintah Provinsi Lampung dalam Melindungi Seni Tapis Lampung, http://pengetahuantradisional.blogspot.com/
[8] Mariani - Irni Rilyansyah, Perlindungan Hukum Atas Folklor Dalam Instrumen Hukum Internasional dan Impelementasinya di Indonesia, http://marianiirnirilyansyah.blogspot.co.id/2013/05/

[9] Pardosi, Tulus Hasudungan, Peran Hukum Kekayaan Intelektual (KI) Terhadap Perlindungan Pengetahuan Tradisional dan Ekspresi Budaya Tradisional, http://www. hukumpedia.com/ulusardosi/peran-hukum-kekayaanintelektual-ki-terhadap-perlindungan-pengetahuantradisional-dan-ekspresi-budaya-tradisional. 